\title{
Animal Husbandry across the Western Roman Empire: Changes and Continuities
}

\author{
Silvia Valenzuela-Lamas ${ }^{1}$ and Umberto Albarella ${ }^{2}$ \\ ${ }^{1}$ Consejo Superior de Investigaciones Cientificas, Barcelona, Spain \\ ${ }^{2}$ Department of Archaeology, University of Sheffield, UK
}

This special issue of the European Journal of Archaeology discusses aspects of animal husbandry in a number of provinces of the Western Roman Empire. In this introduction, we describe the general characteristics of animal busbandry in pre-Roman and Roman times to assess any changes that may have occurred after the Roman conquest. The results suggest that the territoriality typifying the first millennium $B C$ had a significant impact on production, resulting in a decrease in cattle size and frequencies across Europe. Nevertheless, not all the regions reacted in the same way, and regional communities that focused their animal production on pigs implemented more sustainable husbandry practices over time. By bringing together studies carried out across Europe, this journal issue highlights the existence of cases of both change and continuity across the Empire, and the (uneven) impact of the market economy on animal husbandry and dietary practices in climatically different regions.

Keywords: domesticates, husbandry, Iron Age, Roman, Western Europe

\section{INTRODUCTION}

This special issue of the European Journal of Archaeology discusses aspects of animal husbandry in a number of provinces of the Western Roman Empire. It aims to provide a synthesis of animal production before, during, and after the Roman conquest in order to evaluate to what extent the Roman socio-political system caused parallel changes across the Empire. This review is today possible thanks to a combination of factors: over the last twenty years, there has been a significant increase in the number of excavations across Europe and, for many of them, animal remains have been recovered, studied, and published. This now includes southwestern Europe, which previously suffered from a dearth of excavations and published zooarchaeological studies of Iron Age and Roman date (e.g. King, 1999). In addition, current technological opportunities have facilitated the creation of an International Council of Archaeozoology working group on the zooarchaeology of the Roman Empire (ICAZ-RPWG), now counting nearly one hundred members from around the world.

The first meeting of the working group was held at the University of Sheffield in November 2014 and the articles included in this issue are a selection of the papers delivered at that meeting.

Other than a useful resource for specialists, we want this collection to highlight the importance of zooarchaeology for the understanding of the human past, and Roman life in particular. This will be a valuable way to combine zooarchaeology 
with other lines of archaeological evidence, an integrated approach that has often been neglected. In the past fifteen years, some syntheses of Roman archaeology have paid greater attention to the animal bone evidence than in the past (e.g. Ward-Perkins, 2005; Cool, 2006; Todd, 2007). There is, however, still much ground to cover and this journal issue aims to help such endeavour.

\section{Beyond 'Romanization': How Economy and Culture Shape Production}

There has been extensive debate about the implications of the Roman conquest across the Empire, in different provinces, and from different perspectives (e.g. Millett, 1990; Pearce, 2000; Keay \& Terrenato, 2001; Purcell, 2003; Revell, 2005; WardPerkins, 2005; Cool, 2006; Todd, 2007). The term often used to indicate such cultural diffusion is 'Romanization'. The appropriateness of such an expression has been discussed intensively (e.g. Webster \& Cooper, 1996; Woolf, 2014 with references), but here we are not going to pursue such debate further. We will rather focus on the actual evidence for change and continuity and the reasons behind them. We shall therefore first describe the general characteristics of animal husbandry in pre-Roman times in different territories in order to assess whether any change occurred after the Roman conquest.

Changes in animal production may occur at different levels and can affect the type of animals that were exploited, the size of the livestock, and the products used (e.g. traction, wool, meat). Traditionally, these factors have been linked to the ecological conditions of different provinces as well as to their cultural preferences (e.g. Barker, 1975; Crabtree, 1991; King, 1999). There is a clear connection between the two, as cultural traditions are not generated by chance, but developed in conjunction with the need to interact with the environment efficiently and in a sustainable way.

\section{Animal Production in Roman Times: Changes and Continuities}

Multiple works demonstrate that cattle frequencies decreased during the first millennium $\mathrm{BC}$ in various territories across western Europe. From north to south, this is the case in Denmark and northern Germany (e.g. Randsborg, 1985), Britain (e.g. Hambleton, 1999; Albarella, 2007), northern France (e.g. Méniel, 1984), southern France (e.g. Columeau, 2002), and north-eastern Spain (e.g. Albizuri et al., 2010). In central Italy, a decrease in cattle frequencies is attested between the Middle to Recent Bronze Age and the Final Bronze Age (de Grossi Mazzorin, 2002; see Figure 1). In most cases, this coincides in time with the spread of fortifications and territoriality.

In contrast, there was a general increase in cattle and pig frequencies in the conquered territories across the Western Roman Empire and some adjacent territories (e.g. King, 1984; Randsborg, 1985; Lauwerier, 1988; Lepetz, 1996; Peters, 1998; Forest, 2007; Valenzuela-Oliver et al., 2013; Pigière, 2015; see also articles in this issue). For Roman times, it may be claimed that these differences were related to the cultural tradition and socio-political system that came with the Roman conquest, which could have led to different requirements for animal production and preferences in meat diet (e.g. Peters, 1998; King, 1999; Albarella, 2007). A global analysis of livestock proportions across the Roman Empire (King, 1999), however, revealed that the picture was not homogeneous. In particular, Italy had an unusually 

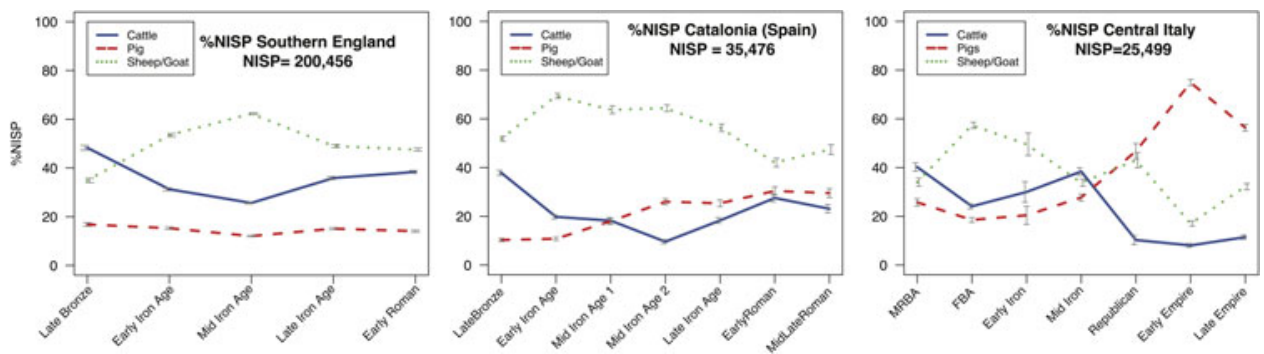

Figure 1. Percentage of the main domesticates in southern Britain, north-eastern Spain, and central Italy between the Late Bronze Age and Roman times. The grey vertical lines show the degree of confidence by chronological phase (two times the standard deviation). Data from Hambleton, 1999; De Grossi Mazzorin, 2002; Albizuri et al., 2010; Colominas, 2013, and authors' data.

high percentage of pig remains, which was not found in any other region of the Empire. Therefore, multiple cultural traditions co-existed in the Empire, and various influences-not all originating in Italy-spread at different times. An example for this could be the spread of the 'cattle pattern' (characteristic of northern Gaul and Germany; King, 1984) to Britain.

The situation for the territories conquered in Republican times in Mediterranean Europe (e.g. southern Gaul and the Iberian Peninsula) is more uncertain, as the available data are still scarce. In these regions, Roman troops would mainly be represented by people coming from Italy. A higher frequency of pig remains in the diet of the Roman soldiers may therefore be expected, although a certain adaptation to available resources should be factored in (King, 1984). Roman Italy saw an increase in pig consumption in the Republican period, though the phenomenon is far more pronounced in later Imperial times (Figure 1).

The frequency of cattle and pig remains generally increased in both Spain and southern France in Roman times (e.g. Renaud, 2012; Colominas, 2013), but this was not a direct consequence of the Roman conquest. The increase in pig remains is already attested in faunal assemblages dated from the third century $\mathrm{BC}$ (before the conquest started) in contexts corresponding to the Iberian and Ligurian cultures (Colomer \& Gardeisen, 1992; Gardeisen, 2003; Iborra, 2004; Valenzuela-Lamas, 2008; Albizuri et al., 2010; Nieto, 2012; see Figure 1). Was this an early Italic influence, parallel to the spread of Campanian A pottery in these regions during the fourth and, especially, the third century BC? Or could it be related to the developing urbanization of the Late Iron Age in these areas? Pigs are better suited to urban contexts than herbivores, which require more open land. The current body of data makes it difficult to identify the exact causes, but it is likely that different factors contributed to the currently observed pattern.

In the case of Roman Spain, the faunal record of Republican Valentia and Baetulo - two colonies of veterans built exnovo in Hispania Citerior-may reflect the fact that Roman soldiers from Italy introduced their high pork diet. The faunal studies of these cities (Colominas, 2013; Iborra, 2017) revealed that pigs outnumbered the other domestic species, which clearly contrasts with indigenous Iberian sites. This, however, did not become a general pattern across the Iberian Peninsula, where sheep and goats (and cattle in the North) continued to be the 
main livestock (Figure 1; see also Colominas et al., this issue). Consequently, and as attested in other provinces, pigs are found to predominate only in some villae and some urban centres or military sites (e.g. Deschler-Erb et al., 2002; Grant, 2007; Bernigaud et al., 2016). The suitability of pigs for urban contexts could have been an influence in some cases, but the predominance of pig remains in villae is likely to be related to Roman influence and taste.

Along with changes, we also see notable examples of continuity across the Empire, especially in rural sites and secondary cities. Cattle continued to be the main species in many sites of the Netherlands, Belgium, Germany, and Switzerland (e.g. Lauwerier, 1988; Peters, 1998; Groot \& Deschler-Erb, 2015; see also Trixl et al., Pigière, Groot, and Deschler-Erb, this issue), and caprines maintained their predominance on rural sites in Britain, southern France, and north-eastern Spain (e.g. Albarella et al., 2008; Rizzetto et al., and Colominas et al., this issue). In the westernmost part of the Empire (present-day Portugal) no major changes in animal husbandry and meat diet have been documented (e.g. Davis, 2006; Valenzuela-Lamas \& Fabião, 2012).

Consequently, a mixture of Italic influences and assimilation to pre-Roman traditions occurred across the Western Roman Empire. We may relate the increase in pig husbandry to the developing urbanization that took place in the Late Iron Age and the consolidation of urban centres in Roman times, but the influence of Roman culture from Italy should not be neglected, and it is particularly marked in villae across the Empire (e.g. Fishbourne palace in Britain (Grant, 2007), and the examples in Spain mentioned above). There are other examples that illustrate how meat diet was diverse across the Empire and travelled with people as part of their cultural identity. These include the case of the 'cattle pattern' in Britain mentioned earlier (King, 1984) and a number of military sites across the Empire (e.g. Kaiseraugst camp in Switzerland, probably with soldiers coming from Spain; see DeschlerErb, this issue).

Cultural transmission, however, did not occur only according to a core-periphery model (i.e. Rome versus the rest of the Empire), and different areas of the Empire certainly influenced each other. The increase of cattle frequencies in earlyconquered territories like Iberia and southern France after the Roman conquest probably reflects changes linked with production, as cattle represent a small proportion of Italian Republican faunal assemblages (Figure 1).

Ecology has also been claimed as one of the key factors influencing animal husbandry regimes (e.g. Barker, 1985; Davis, 1987; among many others). Indeed, as previous works demonstrate, cattle frequencies were generally higher in areas with higher annual rainfall and better pastures (e.g. King, 1999; see also articles in this issue). The existence of common husbandry patterns in the Iron Age, in areas that were significantly different from a cultural and ecological point of view, however, raises the question of the extent to which culture, society, and diet are interrelated, perhaps beyond ecology. As an example of this, southern Britain and north-eastern Spain have different ecological conditions, but experienced similar changes in animal husbandry before and after the Roman conquest (Figure 1). Cattle frequency decreased in the course of the first millennium BC but went up again after the Roman conquest (e.g. King, 1984; Hambleton, 1999; Albarella, 2007; Albizuri et al., 2010; Colominas, 2013). In contrast, some regions with fairly similar climatic conditions, such as north- 
eastern Spain and central Italy, had very different animal production systems both in the Iron Age and in Roman times (Figure 1; de Grossi Mazzorin, 2002; Trentacoste, 2016). The main point Iron Age Britain and north-eastern Spain have in common is the development of chiefdoms and early states during the first millennium BC, in which fortified settlements and an elite of warriors clearly emerged in the archaeological record (e.g. Cunliffe, 1976; Sanmartí, 2004). The main difference between north-eastern Spain and northern-central Italy was the degree of urbanization and social complexity, which was more highly developed in Italy (e.g. Barker \& Gamble, 1985; Christie, 1995; Cifani, 2002). The evidence therefore suggests that socio-political systems contributed to shape animal husbandry production.

\section{Large Roman Cattle: Where and Why?}

Traditionally, large size has been used as a key criterion for assessing productivity in animal husbandry (e.g. Varro's de $R e$ Rustica; Columella's de Re Rustica; Markham, 1648). Larger size means that more labour force and more meat (also more milk and other products) can be obtained per animal. Therefore, large size is seen as a desirable characteristic that farmers may want to achieve and maintain. Husbandry books from the nineteenth century (Loudon, 1839), however, also inform us that large animals were more demanding of fodder and water, and therefore more difficult to maintain. They advise that small animals can be better suited in harsher environments and when available labour is scarce. Consequently, a reduction in the size of the animals could indicate that conditions for large animals were unsuitable.
Many zooarchaeological studies demonstrate that animal size, particularly in cattle, decreased across Europe from the Neolithic to the Iron Age (e.g. Matolcsi, 1970; Bökönyi, 1974; Altuna, 1980; Ijzereef et al., 1981; Méniel, 1984; Vigne, 1988; Valenzuela-Oliver et al., 2013). In Roman times, animal size (most notably cattle) increased only in the conquered territories (e.g. Teichert, 1984; Lauwerier, 1988; Audoin-Rouzeau, 1991; Lepetz, 1996; Peters, 1998; Breuer et al., 1999; Forest \& Rodet-Belarbi, 2002; see also Colominas et al., Frémondeau et al., Groot, Pigière, Rizzetto et al., this issue). Yet, this tendency was not ubiquitous, and cattle size did not change in some areas of Raetia (Trixl et al., this issue) and southern Portugal (Davis, 2006).

Northern and central Italy do, however, show a different trend (Figure 2). In these areas, cattle size decreased from the Neolithic to the Bronze Age, but it increased in the Iron Age, coinciding with the beginning of the Etruscan culture and the installation of some Greek colonies in Latium and Campania (e.g. Riedel, 1994; de Grossi Mazzorin, 1995; de Grossi Mazzorin \& Riedel, 1997; Riedel et al., 2006).

The questions that arise are: Why did these changes in size occur in areas that were so different in climate, environment, and culture? Why did cattle increase in size in Italy in the early first millennium $\mathrm{BC}$, when it was decreasing in other regions?

For the first millennium $\mathrm{BC}$, this decrease in size contrasts with the significant improvements in agriculture and food processing that occurred in this period (e.g. spread of rotation of crops and spring cereals, iron ploughs, rotary querns; e.g. Jäger \& Lozek, 1982; Sherratt, 1993; Van der Veen \& O’Connor, 1998; Alonso, 1999; López et al., 2011). Hypotheses to explain this phenomenon include that 

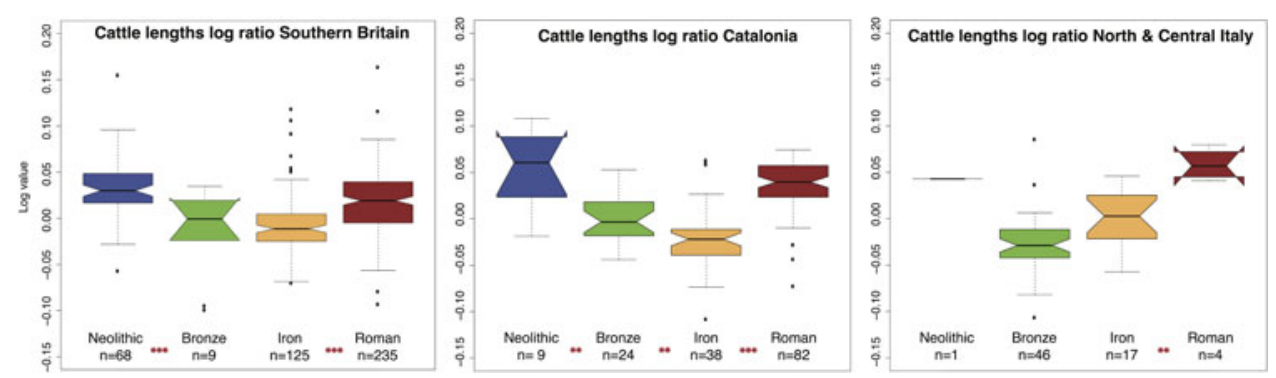

Figure 2. Changes in cattle heights in Britain, Catalonia, and Italy between Neolithic and Roman times. The box contains the 50 per cent of measurements per period, and the notches show the accuracy of the median value (two times the standard deviation). The asterisks show the results of the Mann-U tests with Bonferroni correction. ${ }^{* *}=$ highly significant difference; $* * *$ very bighly significant difference . Data from Saña, 1993; Riedel, 1994; Locker, 2000; Maltby, 2010; Viner, 2010; Albizuri, 2011; Colominas, 2013; Nieto et al., 2014, and authors' data.

small animals would be better suited and more manageable for ploughing (e.g. Clutton-Brock, 1981) and that there was an increase in the proportion of reproductive sub-adults in the population (Manning et al., 2015). It is difficult to explain the constant decrease of cattle size up to the Bronze and the Iron Age in many regions across western Europe based on these hypotheses. After an initial size decrease, a suitable size for ploughing would probably have been achieved, and it is difficult to justify, on the basis of this premise, why Roman cattle were as large as Neolithic cattle and still perfectly suited for ploughing (Figure 2). Regarding mortality profiles, a number of studies indicate that a higher emphasis was placed on 'secondary products' in the Late Neolithic and Bronze Age and, even more, in the Iron Age. This resulted in cattle being slaughtered at an older age (e.g. Bogucki, 1989; Albizuri et al., 2011; Sykes, 2014; Valenzuela-Lamas, 2016). Therefore, the mortality profiles do not support an increase in the proportion of reproductive sub-adults in cattle populations, as more adults would be alive for a longer period to reproduce.

Several studies suggest that animal size is highly related to nourishment regimes (e.g. Hammond, 1960; Widdowson \& Lister, 1991). Other factors that may lead to size change include genetic diversity and flow: interbreeding and increased homozygosity leads to significant decreases in size in captive cattle (e.g. Baker et al., 1945; Sutherland \& Lush, 1962) and it also happens in humans (McQuillan et al., 2012; Joshi et al., 2015). More critically, interbreeding also entails a decrease in milk, fat, and protein yields in cattle, as well as decreased fertility (Pryce et al., 2014).

In the Iron Age, either the improvements in agriculture did not result in better nourishment of livestock in many regions, and/or there was a significant reduction in the genetic diversity at a local level, perhaps as a consequence of the territorialization that characterizes this period. The Roman Empire-with the huge volume of trade that developed between regions-changed this picture completely. The larger scale economic structure entailed a higher degree of specialization, thus allowing the farmers to adapt their production to the crops and animals better suited to the local conditions, rely on trade for other supplies, and re-invest the revenues from the trade of their own products (Ward-Perkins, 2005). 
In addition, the political superstructure of the Empire made it possible to build and maintain substantial public facilities, such as aqueducts, roads, and ports, which enhanced productivity and connectivity even further.

Strontium isotope analysis from cattle teeth demonstrates that not only soldiers, amphorae, and crops travelled within the Roman network of roads and maritime trade, but also animals (Minniti et al., 2014). Consequently, enhanced genetic flow and better nourishment became possible in Roman times, in contrast with previous and later periods. Yet, not all animals in every province experienced growth at the same time and to the same extent (see Frémondeau et al., this issue), and some livestock within the Empire remained small (e.g. in the RomanMediterranean milieu in Raetia, see Trixl et al., this issue). Further investigations are needed to establish to what extent small animals and local breeds could have been elements of cultural identity and resistance (as suggested by Classical sources, such as Tacitus, Germania, V). Alternatively, or additionally, these small animals may have been better suited to the harsh environmental conditions and the kind of smallscale exploitation that persisted in some of the conquered territories.

\section{Culture and Politics: The Roman Empire and Changes in Economy, Territories, AND Mobility}

As mentioned earlier, the Bronze and the Iron Ages are periods characterized by increased social differentiation and progressive territoriality. This is perceivable in the archaeological record by the expansion of fortifications across Europe (e.g. Johnson \& Earle, 1987; Py, 1993; Brun, 1995; Collis, 2003; Sanmartí, 2004). Likewise, the spread of warrior equipment and weapons suggests that this process entailed a significant increase of warfare and probably involved the protection of boundaries between territories.

In the Iron Age, ploughing with iron ploughshares made it possible to cultivate new fields. The expansion of agriculture resulted in a reduction of the surface devoted to pasture. The archaeological record also suggests a notable demographic increase, after the introduction of iron technologies (e.g. Van der Veen \& O’Connor, 1998; Alonso, 1999; López et al., 2011). In this context of increased territoriality and expansion of agriculture, it is reasonable to think that cattle were the most difficult animals to herd, as they are the most demanding in water and fresh pasture, and require the best soils, where tall grass can grow. Additionally, land exploitation probably took place on a small scale, therefore reducing the need for large animals. Interbreeding would have significantly increased, leading to a decrease in animal size and productivity.

Consequently, we may explain cattle frequency and size decreases in the first millennium $\mathrm{BC}$ through a combination of factors:

- Expansion of agriculture and demographic growth, with subsequent reduction of the areas of pasture in the hinterland of villages and emerging urban centres;

- Restriction of movement, consequent to the creation of military-protected boundaries;

- Reduced mobility of livestock, which entailed higher ratios of interbreeding.

This reduced mobility dramatically changed in Roman times. The creation of roads and the expansion of maritime trade promoted mobility within the Empire and made long-distance travelling easier and safer. In addition, larger animals, especially cattle, were better suited to the Roman 
economy. Commerce helped farmers to focus on crops for which local conditions were appropriate and to invest the profit obtained through trade in technical improvements.

Yet, regional differences persisted, and animal husbandry and meat diet changed to various degrees in different regions. Most contributors to this special issue highlight that changes were not homogeneous within named provinciae or neighbouring regions, and that changes did not affect all sites in the same way. Urban sites, villae, and military sites across the Empire display a higher degree of change, whereas rural sites more often retained forms of production that were closer to those of the Iron Age.

Significant variation exists between sites located in the same region and, more clearly, between regions. Despite substantial changes, some Iron Age traditions survived in the Roman period. This indicates that it was not Roman policy to obliterate the underlying local economies; rather, the Roman regime tried to integrate them, making allowances for the economic, environmental, and social needs of each region. Individuals and communities travelling across the Empire maintained some of their dietary preferences and, in some cases, they are recognizable in the archaeological record (e.g. in the colonies of veteran soldiers in Valentia and Baetulo in Hispania, the Kaiseraugst camp in Germany, or Fishbourne palace in Britain, all mentioned earlier).

The general questions discussed here and the more detailed analyses that form this special issue show that zooarchaeology represents a valuable tool to recognize cultural preferences and assess the impact of socio-political and economic systems on animal husbandry. The territoriality that characterizes the first millennium BC had a significant effect on production, resulting in a decrease in cattle size and frequencies.
Nevertheless, not all the regions reacted in the same way. Regional communities that focused their animal production on pigs rather than herbivores-i.e. northern Gaul and northern-central Italy-implemented more sustainable husbandry practices over time, as they reduced the competition between animals and cultivated land. In all conquered territories, the Romans built on the existing production systems and brought new dietary traditions and some exogenous species. Overall, the Romans expanded the market economy to unprecedented levels. After the collapse of longdistance trade at the end of the Western Roman Empire, most regions developed again an un-specialized animal husbandry style, bearing some similarities with that of the Iron Age (see, e.g., GrauSologestoa, 2015; Rizzetto et al., this issue). By bringing together studies carried out in different regions, this special issue highlights cases of both change and continuity across the Empire, and the (uneven) impact of the market economy on animal husbandry and dietary practices in climatically different regions.

\section{ACKNowledgements}

The articles published in this issue originate, with changes, from the inaugural meeting of the ICAZ working group on the zooarchaeology of the Roman period, which we organized in Sheffield (UK) in November 2014 with the support of the Institut Européen d'Histoire et des Cultures de l'Alimentation (IEHCA). We would like to thank all contributors to this issue as well as those who delivered papers at the conference. We also thank the European Commission for financial support with the IEF-Marie Curie Fellowship IEF2010/130428, as part of which some of the research and the organization of the conference was undertaken. 
Finally, we are grateful to the editorial board of the European Journal of Archaeology for accepting our publication proposal and to the editor, Robin Skeates, for guidance through the process and for his patience.

\section{REFERENCES}

Albarella, U. 2007. The End of the Sheep Age: People and Animals in the Late Iron Age. in: C. Haselgrove \& T. Moore, eds. The Later Iron Age in Britain and Beyond. Oxford: Oxbow Books, pp. 389-402.

Albarella, U., Johnstone, C. \& Vickers, K. 2008. The Development of Animal Husbandry from the Late Iron Age to the End of the Roman Period: A Case Study from South-East Britain. Journal of Archaeological Science, 35: 1828-48.

Albizuri, S. 2011. La ofrenda animal durante el Bronce Inicial en Can Roqueta II (Sabadell, Vallès Occidental). Arqueozoología del ritual funerario (unpublished $\mathrm{PhD}$ dissertation, University of Girona).

Albizuri, S., Alonso, N. \& Cachero, J. 2011. Economia i canvi social a Catalunya durant l'edat del bronze i la primera edat del ferro. In: S. Valenzuela-Lamas, N. Padrós, M.C. Belarte \& J. Sanmartí, eds. Economia agropecuària $i$ canvi social a partir de les restes bioarqueològiques. El primer mil-lenni aC a la Mediterrània occidental (Arqueo Mediterrània 12). Barcelona: Universitat de Barcelona, pp. 11-36.

Albizuri, S., Nieto, A. \& Valenzuela, S. 2010. Canvis en l'alimentació càrnia a Catalunya entre els segles IX i III aC. Complutum Extra, 9: 199-210.

Alonso, N. 1999. De la llavor a la farina: els processos agricoles protohistòrics a la Catalunya Occidental (Monographies d'Archéologie Méditerranéenne, 4). Lattes: CNRS.

Altuna, J. 1980. Historia de la domesticación en el País Vasco desde sus orígenes hasta la romanización. Munibe, 32: 9-163.

Audoin-Rouzeau, F. 1991. La taille du boeuf domestique en Europe de l'Antiquité aux temps modernes (Fiches d'ostéologie animale pour l'archéologie, Série B, Mammifères, 2). Juan-les-Pins: Association pour la Promotion et la Diffusion des Connaissances Archéologiques.

Baker, G.A., Mead, S.W. \& Regan, W.M. 1945. Effect of Inbreeding on the Growth Curves of Height at Withers, Weight, and Heart Girth of Holstein Females. Journal of Dairy Science, 28: 607-10.

Barker, G. \& Gamble, C. 1985. Beyond Domestication: A Strategy for Investigating the Process and Consequence of Social Complexity. In: G. Barker \& C. Gamble, eds. Beyond Domestication: Subsistence Archaeology and Social Complexity in Prehistoric Europe. London: Academic Press, pp. 1-31.

Barker, G.W.W. 1975. Prehistoric Territories and Economies in Central Italy. In: E.S. Higgs, ed. Palaeoeconomy. Cambridge: Cambridge University Press, pp. 111-75.

Barker, G.W.W. 1985. Prehistoric Farming in Europe. Cambridge: Cambridge University Press.

Bernigaud, N., Ouzoulias, P., Lepetz, S., Wiethold, J., Zech-Matterne, V., Séguier, J.M. \& Reddé, M. 2016. Exploitations agricoles et pratiques agropastorales dans les campagnes du nord-est de la Gaule (IIe s. av. J.-C.-Ve s. ap. J.-C.) : l'apport des données de l'archéologie préventive d'Île-de-France et de Lorraine. In: N. Reddé, ed. Méthodes d'analyse des différents paysages ruraux dans le Nord-Est de la Gaule romaine. Études comparées, pp. 63-137 [online] [accessed 6 April 2017]. Available at <https://hal. archives-ouvertes.fr/hal-01253470>.

Bogucki, P. 1989. The Exploitation of Domestic Animals in Neolithic Central Europe. In: P.J. Crabtree, D.V. Campana \& K. Ryan, eds. Early Animal Domestication and its Cultural Context, 6. Philadelphia: University of Pennsylvania, Museum of Archaeology, pp. 118-34.

Bökönyi, S. 1974. History of Domestic Animals in Central and Eastern Europe. Budapest: Akadémiai Kiadó.

Breuer, G., Rehazek, A. \& Stopp, B. 1999. Größenveränderungen des Hausrindes. Osteometrische Untersuchungen großer Fundserien aus der Nordschweiz von der Spätlatènezeit bis ins Frühmittelalter am Beispiel von Basel, Augst (Augusta Raurica) und Schleitheim-Brüel. Jabtesberichte aus August und Kaiseraugst, 20: 207-28.

Brun, P. 1995. From Chiefdom to State Organization in Celtic Europe. In: B. Arnold 
\& D.B. Gibson, eds. Celtic Chiefdom, Celtic State, The Evolution of Complex Social Systems in Prehistoric Europe. Cambridge: Cambridge University Press, pp. 13-25.

Christie, N. ed. 1995. Settlement and Economy in Italy, 1500 BC-AD 1500: Papers of the Fifth Conference of Italian Archaeology. Oxford: Oxbow Books.

Cifani, G. 2002. Notes on the Rural Landscape of Central Tyrrhenian Italy in the 6th-5th c. BC and its Social Significance. Journal of Roman Archaeology, 15: 247-60.

Clutton-Brock, J. 1981. Domesticated Animals from Early Times. London: British Museum (Natural History).

Collis, J. 2003. The Celts: Origins, Myths and Inventions. Stroud: Tempus.

Colomer, A. \& Gardeisen, A. 1992. Premier bilan sur la consommation des animaux d'élevage et de chasse dans la ville de Lattara (fin du IVe av. n. è.-milieu du 1er s. de n. è.). Lattara, 5: 91-110.

Colominas, L. 2013. Arqueozoología y Romanización, Producción, distribución y consumo de animales en el nordeste de la Peninsula Ibérica entre los siglos $V$ ane- $V$ dne (British Archaeological Reports International Series 2480). Oxford: Archaeopress.

Columeau, P. 2002. Alimentation carnée en Gaule du sud (VII av. J.-C.-XIV s.). Aixen-Provence: Presses universitaires de Provence.

Columella (Lucius Iunius Modeartus Columella). On Agriculture (De Re Rustica), trans. by Harrison B. Ash (Loeb Classical Library). Cambridge (MA): Harvard University Press \& London: Heinemann.

Cool, H.E.M. 2006. Eating and Drinking in Roman Britain. Cambridge: Cambridge University Press.

Crabtree, P.J. 1991. Introduction. In: P.J. Crabtree \& K. Ryan, eds. Animal Use and Culture Change. Philadelphia: University of Pennsylvania, Museum of Archaeology, pp. 5-6.

Cunliffe, B.W. 1976. The Origins of Urbanisation in Britain. In: B.W. Cunliffe \& T. Rowley, eds. Oppida: The Beginning of Urbanisation in Barbarian Europe (BAR Supplementary Series 11). Oxford: British Archaeological Reports, pp. 135-62.
Davis, S.J.M. 1987. The Archaeology of Animals. London: Batsford.

Davis, S.J.M. 2006. Faunal Remains from Alcáçova de Santarém, Portugal (Trabalhos de Arqueologia 43). Lisbon: Instituto Português de Arqueologia.

de Grossi Mazzorin, J. 1995. Economie di allevamento in Italia centrale dalla media età del bronzo alla fine dell'età del ferro. In: N. Christie, ed. Settlement and Economy in Italy 1500 BC-AD 1500, Papers of the 5th Conference of Italian Archaeology. Oxford: Oxbow Books, pp. 167-77.

de Grossi Mazzorin, J. 2002. Some Considerations about the Evolution of the Animal Exploitation in Central Italy from the Bronze Age to the Classical Period. In: B.S. Fritzell, ed. PECUS. Man and Animal in Antiquity. Rome: Swedish Institute, pp. 38-49.

de Grossi Mazzorin, J. \& Riedel, A. 1997. La fauna delle terramare. In: $M$ Bernabò Brea, A. Cardarelli \& M. Cremaschi, eds. Le Terramare. La più antica civilità padana. Milano: Electa, pp. 475-80.

Deschler-Erb, S., Schibler, J. \& Hüster Plogmann, H. 2002. Viehzucht, Jagd und Fischfang. In: L. Flutsch, U. Niffeler \& F. Rossi. Die Römerzeit in der Schweiz. Die Schweiz vom Paläolithikum bis zum frühen (Mittelalter 5 - SPM V). Basel: Archäologie Schweiz, pp. 165-71.

Forest, V. 2007. Indices archéozoologiques de ruralité en Gaule narbonnaise : l'exemple de la triade domestique en Bas-Languedoc. In: C. Raynaud, R. Sablayrolles \& F. Trément, eds. Les formes de l'babitat rural gallo-romain. Terminologies et typologies à l'épreuve des réalités archéologiques, Colloque AGER VIII. Bordeaux: Editions de la Fédération Aquitania, pp. 22-24.

Forest, V. \& Rodet-Belarbi, I. 2002. A propos de la corpulence des bovins en France durant les périodes historiques. Gallia, 59: 273-306.

Gardeisen, A. 2003. Contribution de l'archéozoologie des grands mammiferes à l'étude d'un espace ouvert en contexte urbain: La zone 123 (Lattes/SaintSauveur, Hérault). Lattara, 16: 169-84.

Grant, A. 2007. Domestic Animals and their Uses. In: M. Todd, ed. A Companion to Roman Britain. Oxford: Blackwell, pp. 371-92.

Grau-Sologestoa, I. 2015. Livestock Management in Spain from Roman to Post- 
Medieval Times: A Biometrical Analysis of Cattle, Sheep/Goat and Pig. Journal of Archaeological Science, 54: 123-34.

Groot, M. \& Deschler-Erb, S. 2015. Market Strategies in the Roman Provinces: Different Animal Husbandry Systems Explored by a Comparative Regional Approach. Journal of Archaeological Science: Reports, 4: 447-60.

Hambleton, E. 1999. Animal Husbandry Regimes in Iron Age Britain: A Comparative Study of Faunal Assemblages from Iron Age Sites (BAR British Series 282). Oxford: British Archaeological Reports.

Hammond, J. 1960. Farm Animals: Their Breeding, Growth and Inheritance. London: Edward Arnold.

Iborra, M.P. 2004. La ganadería y la caza desde el Bronce Final hasta el Ibérico Final en el territorio valenciano. Valencia: Diputación Provincial de Valencia, Servicio de investigación prehistórica.

Iborra, M.P. 2017. Arqueozoología de época romana en el País Valenciano. Archaeofauna, 26: 23-38.

Ijzereef, G.F, van Regteren Altena, J.F. \& Kuijper, W.J. 1981. Bronze Age Animal Bones from Bovenkarspel: The Excavations at Het Valkje (Nederlandse Oudheden, 10, Project Noord- Holland 1). Amersfoort: Rijksdienst voor het Oudheidkundig Bodemonderzoek.

Jäger, K.D. \& Lozek, V. 1982. Environmental Conditions and Land Cultivation during the Urnfield Bronze Age in Central Europe. In: A. Harding, ed. Climatic Change in Later Prehistory. Edinburgh: Edinburgh University Press, pp. 162-78.

Johnson, A.V. \& Earle, T. 1987. The Evolution of Human Societies: From Foraging Group to Agrarian State. Stanford: Stanford University Press

Joshi, P.K., Esko, T., Mattsson, H., et al. 2015. Directional Dominance on Stature and Cognition in Diverse Human Populations. Nature, 523: 459-62. doi: 10.1038/nature14618

Keay, S. \& Terrenato, N. 2001. eds. Italy and the West: Comparative Issues in Romanization. Oxford: Oxbow Books.

King, A. 1999. Diet in the Roman World: A Regional Inter-Site Comparison of the Mammal Bones. Journal of Roman Archaeology, 12: 168-202.
King, A.C. 1984. Animal Bones and the Dietary Identity of Military and Civilian Groups in Roman Britain, Germany and Gaul. In: T.F.C. Blagg \& A.C. King, eds. Military and Civilian in Roman Britain (BAR British Series 136). Oxford: British Archaeological Reports, pp. 187-217.

Lauwerier, R.C.G.M. 1988. Animals in Roman Times in the Dutch Eastern River Area. Amersfoort: Rijksdienst voor het Oudheidkundig Bodemonderzoek.

Lepetz, S. 1996. Effets de la romanisation sur l'élevage et la diète carnée dans les établissements ruraux du nord de la Gaule. L'exemple de l'augmentation de la stature des animaux domestiques. In: D. Bayard \& J.-L. Collart, eds. De la ferme indigène à la villa gallo-romaine (Revue Archéologique de Picardie numéro spécial 11). Amiens: Société de Préhistoire du Nord et de la Picardie, pp. 317-24.

Locker, A. 2000. Animal Bone. In: A.J. Lawson \& M.J. Allen, eds. Potterne 19825: Animal Husbandry in Later Prehistoric Wiltshire. Salisbury: Wessex Archaeology, pp. 101-19.

López, D., Valenzuela, S. \& Sanmartí, J. 2011. Economia i canvi sociocultural a Catalunya durant l'edat del ferro. In: S. Valenzuela-Lamas, N. Padrós, M.C. Belarte \& J. Sanmartí, eds. Economía agropecuaria y cambio social durante el primer milenio a $C$ en el Mediterráneo occidental, a partir de restos bioarqueológicos (Arqueomediterrània 12). Barcelona: Universitat de Barcelona, pp. 71-92.

Loudon, J.C. 1839. An Encyclopedia of Agriculture. London: Longman, Orme, Brown, Green \& Longmans.

Maltby, M. 2010. Feeding a Roman Town: Environmental Evidence from Excavations in Winchester, 1972-1985. Winchester: Winchester Museums Service.

Manning, K., Timpson, A., Shennan, S. \& Crema, E. 2015. Size Reduction in Early European Domestic Cattle Relates to Intensification of Neolithic Herding Strategies. PLoS ONE, 10(12): e0141873. doi:10.1371/journal.pone.0141873

Markham, G. 1648. A Way to get Wealth: by Approued Rules of Practice in Good Husbandry and Huswiferie. London: Roger Jackson.

Matolcsi, J. 1970. Historische Erforschung der Körpergrösse des Rindes auf Grund von 
ungarischem Knochenmaterial. Zeitschrift für Tierzüchtung und Züchtungsbiologie, 63: 155-94.

McQuillan, R., Eklund, N., Pirastu, N., et al. 2012. Evidence of Inbreeding Depression on Human Height. PLoS Genet 8(7): e1002655. doi:10.1371/journal.pgen.1002655

Méniel, P. 1984. Contribution à l'bistoire de lélevage en Picardie du Néolithique à la fin de l'Age du Fer (Revue archéologique de Picardie, numéro spécial). Amiens: Société de Préhistoire du Nord et de la Picardie.

Millett, M. 1990. The Romanization of Britain. Cambridge: Cambridge University Press.

Minniti, C., Valenzuela-Lamas, S., Evans, J. \& Albarella, U. 2014. Widening the Market: Strontium Isotope Analysis on Cattle Teeth from Owslebury (Hampshire, UK) Highlights Changes in Livestock Supply between the Iron Age and the Roman Period. Journal of Archaeological Science, 42: 305-14.

Nieto, A. 2012. Entre el consum i l'afecte. La interacció entre els animals i les comunitats protohistòriques de la plana occidental catalana (segles VII-IV aC) (unpublished $\mathrm{PhD}$ dissertation, University of Lleida).

Nieto, A., Moya, A., López, J.B. \& Agustí, B. 2014. Ofrenes o deixalles ? El cas dels bovins (Bos taurus) en context funerari del jaciment del bronze ple de Minferri (Lleida, Catalunya). In: A. Gardeisen \& C. Chandezon, eds. Equidés et bovidés de la Méditerranée antique, rites et combats, jeux et savoirs (Monographies d'archéologie méditerranéenne, Hors-Série 6). Lattes: CNRS - UMR 5140, pp. 53112.

Pearce, J. 2000. Burial, Society and Context in the Provincial Roman World. In: J. Pearce, M. Millett \& M. Struck, eds. Burial, Society and Context in the Roman World. Oxford: Oxbow Books, pp. 1-10.

Peters, J. 1998. Römische Tierbaltung und Tierzucht: eine Synthese aus archäozoologischer Untersuchung und schriftlich-bildlicher Überlieferung (Passauer Universitätsschriften zur Archäologie 5). Rahden: Marie Leidorf.

Pigière, F. 2015. L'archéozoologie. In: J.-C. Demanet \& F. Vilvorder, eds. Liberchies VI, Vicus Gallo-Romain. Louvain-LaNeuve: Université catholique de Louvain, pp. 533-49.
Pryce, J.E., Haile-Mariam, M., Goddard, M.E. \& Hayes, B.J. 2014. Identification of Genomic Regions Associated with Inbreeding Depression in Holstein and Jersey Dairy Cattle. Genetics Selection Evolution, 46(1): 71. doi: 10.1186/s12711014-0071-7

Purcell, N. 2003. The Way We Used to Eat: Diet, Community, and History at Rome. The American Journal of Philology, 124: 32-58.

Py, M. 1993. Les Gaulois du Midi, de la fin de l'âge du Bronze à la conquête romaine. Paris: Hachette.

Randsborg, K. 1985. Subsistence and Settlement in Northern Temperate Europe in the First Millennium AD. In: G. Barker \& C. Gamble, eds. Beyond Domestication in Prehistoric Europe: Investigations in Subsistence Archaeology and Social Complexity. London: Academic Press, pp. 233-65.

Renaud, A. 2012. Alimentation carnée et gestion des populations animales sur le territoire de la cité de Nîmes (Hérault et Gard, IIème s. av. J.-C.-IIème s. ap. J.-C.) (unpublished $\mathrm{PhD}$ dissertation, University of Montpellier - CNRS UMR 5140).

Revell, L. 2005. The Roman Life Course: A View from the Inscriptions. European Journal of Archaeology, 8: 43-63.

Riedel, A. 1994. Archeozoological Investigations in North-Eastern Italy: The Exploitation of Animals since the Neolithic. Preistoria Alpina, 30: 43-94.

Riedel, A., Tasca, G. \& Tecchiati, U. 2006. I resti faunistici del V sec. a.C. di Centes di Gradiscutta di Varmo (UD). In: G. Malerba \& P. Visentini, eds. Atti del $4^{\circ}$ Convegno nazionale di archeozoologia. Quaderni del Museo Archeologico del Friuli Occidentale, 6: 293-300.

Saña, M. 1993. Estudi de les relacions entre grup humà-recursos animals. Dinàmica del procés de domesticació animal al neolític antic català. L'exemple de la Draga (Banyoles-Pla de l'Estany). Treball de recerca, Universitat Autònoma de Barcelona.

Sanmartí, J. 2004. From Local Groups to Early States: The Development of Complexity in Protohistoric Catalonia. Pyrenae, 35: 7-42.

Sherratt, A. 1993. What Would a Bronze-Age World System Look Like? Relations 
between Temperate Europe and the Mediterranean in Later Prehistory. Journal of European Archaeology, 2: 1-56.

Sutherland, T.M. \& Lush, J.L. 1962. Effects of Inbreeding on Size and Type in Holstein-Friesian Cattle. Journal of Dairy Science, 45: 390-95.

Sykes, N. 2014. Beastly Questions. London: Bloomsbury Academic.

Tacitus (Cornelius Tacitus). Germania. In: Tacitus in five volumes, Germania, trans. by M. Hutton, revised by E. H. Warmington (Loeb Classical Library). Cambridge (MA): Harvard University Press \& London: Heinemann.

Teichert, M. 1984. Size Variation in Cattle from Germania Romana and Germania Libera. In: C. Grigson \& J. CluttonBrock, eds. Animals and Archaeology 4: Husbandry in Europe (BAR International Series 227). Oxford: British Archaeological Reports, pp. 93-104.

Todd, M. ed. 2007. A Companion to Roman Britain. Oxford: Blackwell.

Trentacoste, A. 2016. Etruscan Foodways and Demographic Demands: Contextualizing Protohistoric Livestock Husbandry in Northern Italy. European Journal of Archaeology, 19: 279-315.

Valenzuela-Lamas, S. 2008. Alimentació $i$ ramaderia al Penedès durant la protohistòria (segles VII-III aC). Barcelona: Societat Catalana d'Arqueologia.

Valenzuela-Lamas, S. 2016. Alimentation et élevage à Althiburos à partir des restes fauniques. In: N. Kallala, J. Sanmartí, M.C. Belarte, et al. eds. Althiburos II. L'aire du capitole et dans la nécropole méridionale (Documenta 18). Tarragona: Instituto Catalán de Arqueología Clásica, pp. 42148.

Valenzuela-Lamas, S. \& Fabião, C. 2012. Ciervos, ovejas y vacas: el registro faunístico de Mesas do Castelinho. In: M. de Deus, ed. Actas do $V$ Congresso de Arqueologia do Sudoeste Peninsular. Almodôvar: Município de Almodôvar, pp. 413-32.

Valenzuela-Oliver, A., Alcover, J.A. \& Cau, M.A. 2013. Tracing Changes in Animal Husbandry in Mallorca (Balearic Islands, Western Mediterranean) from the Iron Age to the Roman Period. In: M. Groot, D. Lentjes \& J. Zeiler, eds. Barely
Surviving or More Than Enough? Leiden: Sidestone Press, pp. 201-23.

Van der Veen, M. \& O'Connor, T. 1998. The Expansion of Agricultural Production in Later Iron Age and Roman Britain. In: J. Bayley, ed. Science in Archaeology: An Agenda for the Future. London: English Heritage, pp. 127-43.

Varro (Marcus Terentius Varro). On Agriculture (De Re Rustica). In: Cato and Varro on Agriculture, trans. by W.D. Hooper, revised by H.B. Ash (Loeb Classical Library). Cambridge (MA): Harvard University Press \& London: Heinemann.

Vigne, J.-D. 1988. Les mammiferes post-glaciaires de Corse, étude archéozoologique (XXVIe suppl. à Gallia Préhistoire). Paris: CNRS.

Viner, S.M. 2010. A Diachronic study of Sus and Bos Exploitation in Britain from the Early Mesolithic to the Late Neolithic (unpublished $\mathrm{PhD}$ dissertation, University of Sheffield).

Ward-Perkins, B. 2005. The Fall of Rome and the End of Civilization. Oxford: Oxford University Press.

Webster, J. \& Cooper, N. eds. 1996. Roman Imperialism: Post-colonial Perspectives (Leicester Archaeology Monographs 3). Leicester: School of Archaeological Studies.

Widdowson, E.M. \& Lister, D. 1991. Nutritional Control of Growth. In: A.M. Pearson \& T.R. Dutson, eds. Growth Regulation in Farm Animals. Advances in Meat Research, 7. London: Elsevier Applied Sience, pp. 67-101.

Woolf, G. 2014. Romanization 2.0 and its Alternatives. Archaeological Dialogues, 21: $45-50$.

\section{Biographical Notes}

Silvia Valenzuela-Lamas is a researcher in the Consejo Superior de Investigaciones Científicas (Institució Milà i Fontanals, Barcelona). Together with Umberto Albarella, she founded and coordinates the Roman Period Working Group of the 
International Council of Archaeozoology (ICAZ). She is currently PI of the ERC-Starting Grant 'ZooMWest: Zooarchaeology and Mobility in the Western Mediterranean' (2017-2021).

Address: Consejo Superior de Investigaciones Científicas, Institució Milà i Fontanals, C/ Egipcíaques 15, 08001, Barcelona, Spain. [email: svalenzuela@imf.csic.es]

Umberto Albarella is a Reader in Zooarchaeology at the University of
Sheffield. He has undertaken research in archaeology for thirty-five years and has worked for several universities and other institutions in England and Italy. His main research interests range from animal domestication, to the ritual use of animals, herding and mobility, and the history of animal husbandry. He is also an advocate for social justice in archaeology.

Address: Department of Archaeology, University of Sheffield, Northgate House, Sheffield, S1 4ET, UK. [email: u.albarella@ sheffield.ac.uk]

\section{L'élevage dans l'Empire romain d'Occident : transformations et continuité}

Ce numéro spécial de la revue European Journal of Archaeology est consacré à l'élevage dans les provinces de l'Empire romain d'Occident. Cette introduction sert de description des traits généraux de l'élevage aux époques préromaines et romaines et nous permet d'évaluer les changements qui auraient pu avoir lieu après la conquête romaine. Les résultats suggèrent que la territorialité qui marquait le premier millénaire av. J.-C eut une profonde influence sur l'exploitation des animaux domestiques, avec une réduction de la taille et l'apport des bovins à travers l'Europe. Cependant toutes les régions n'ont pas réagi de la même manière et les communautés qui se sont concentrées sur l'élevage des porcs ont mis en ceuvre des pratiques d'élevage plus durables au cours du temps. Ce numéro spécial met l'accent sur des cas de transformation et de continuité à travers l'empire romain par l'entremise d'études de cas provenant de diverses régions d'Europe et met en évidence les effets (inégaux) de l'économie de marché sur l'élevage et les habitudes alimentaires dans des régions aux climats différents. Translation by Madeleine Hummler

Mots-clés: animaux domestiques, élevage, âge du Fer, époque romaine, Europe occidentale

\section{Tierhaltung im weströmischen Reich: Wechsel und Kontinuität}

Diese Sonderausgabe der Zeitschrift European Journal of Archaeology ist der Tierhaltung in verschiedenen Provinzen des weströmischen Reiches gewidmet. Diese Einleitung beschreibt die allgemeinen Eigenschaften der Viehzucht in der vorrömischen und römischen Zeit, um die Veränderungen, die nach der römischen Eroberung stattgefunden bätten, zu berwerten. Die Ergebnisse zeigen, dass die Territorialität, die das erste vorchristliche Jahrtausend gekennzeichnet, einen maßgeblichen Einfluss auf die Tierproduktion hatte, die eine Minderung der Größe und Anteils der Rinder in Europa zu Folge hatte. Alle Gebiete haben aber nicht gleich reagiert und regionale Gemeinschaften, die sich auf die Schweinezucht konzentrierten, haben im Laufe der Zeit nachhaltigere Tierhaltungspraktiken entwickelt. Durch die Zusammenfübrung von Fallstudien aus ganz Europa betont diese Sondernummer, dass es im römischen Reich Fälle sowohl von Wechsel wie von Kontinuität gab und, dass der Einfluss der Marktwirtschaft auf die Tierhaltung und die Ernährungsgerwohnheiten in klimatisch verschiedenen Gebieten ungleich war. Translation by Madeleine Hummler

Stichworte: Vieh, Tierhaltung, Eisenzeit, Römerzeit, Westeuropa 